\title{
Det største, det minste og det mest komplekse
}

Filantropi - det å handle til beste for andre, uten å tenke på økonomisk vinning - er en lang tradisjon i USA. Vi ble minnet om dette da Bill Gates besøkte Oslo for kort tid siden. Flere titalls milliarder dollar er satt inn i den veldedige stiftelsen Bill \& Melinda Gates Foundation. Ifølge Bill Gates var startpunktet en lang samtale han hadde med sin kone om hvordan de skulle forvalte formuen de var så heldige å ha, slik at den fikk størst mulig effekt i verdenssamfunnet. I litt mindre skala blir vi minnet om filantropitradisjonen i USA hver gang vi som forskere besøker ledende amerikanske universiteter. Mange av våre kolleger sitter i professorater oppkalt etter kvinner eller menn som har donert sin formue til en lærestol.

Fred Kavli er en mann som går rett inn i den amerikanske filantropitradisjonen. Han har bestemt seg for å gi mesteparten av sin formue til forskning. «It's so delicious to get rid of it,» sier han (1). Gjennom Fred Kavli får vi her i Norge filantropien nært innpå livet. Fred Kavli er fra den lille bygda Eresfjord, i Nesset kommune øst for Molde. Han bygde opp sin formue i USA og har bestemt seg for å sette denne inn i forskning gjennom opprettelse av priser, forskningssentre og lærestoler som bærer hans navn. Kavliprisene (2) utdeles i Oslo, i regi av Det Norske Videnskaps-Akademi. Norge har også ett av de 15 Kavlisentrene som er opprettet så langt. Det norske Kavlisenteret (3) ligger i Trondheim og er bygd opp rundt den fremragende hjerneforskningen til Edvard og May-Britt Moser.

Kavlis filosofi uttrykkes best gjennom følgende sitat: «The curiosity of the human being is what has brought us where we are today, and I have complete confidence that it will take us where we need to be in the future» (4). Gjennom priser og sentre vil han støtte den nysgjerrighetsdrevne grunnforskningen. Den mer anvendte forskningen vil alltid få finansiering, mener han. Grunnforskningen er mer utsatt, og den vil han bidra til å sikre.

Kavliprisene er samarbeidsprosjekt mellom Det Norske Videnskaps-Akademi, Kavli Foundation, og Kunnskapsdepartementet. Prisen deles ut i tre fagområder: astrofysikk, nanovitenskap og nevrovitenskap. Til forskning om det største, det minste og det mest komplekse, for å sitere Kavli (5). Prisen i hvert felt er på 1 million amerikanske dollar. Det er H.M. Kongen som overrekker prisen. Utdelingen skjer annethvert år. Første gang var i 2008 og neste gang blir 2014. De tre priskomiteene utpekes av Det Norske Videnskaps-Akademi etter forslag fra The National Academy of Sciences (USA), The Royal Society (UK), The Max Planck Society (Tyskland) samt vitenskapsakademiene i Kina og Frankrike.

Det er prisene i nevrovitenskap som ligger nærmest det medisinske fagfeltet. Mye av den grunnforskningen som er belønnet gjennom disse prisene har direkte relevans for nevrologisk sykdom. En av prisene for 2012 gikk til amerikaneren Ann Graybiel - en nestor i forskningen på de strukturene i hjernen som står sentralt i innlæring av motoriske ferdigheter (6). Denne forskningen vil utvilsomt få betydning for vår forståelse av viktige tilstander slik som schizofreni og Parkinsons sykdom. Graybiel delte prisen med Winfried Denk og Cornelia Bargmann. Denks innsats i metodeutvikling kommer til nytte for alle forskere som benytter laserteknologi til å studere hjernefunksjon og sykdomsmekanismer i levende organismer (7). Ved hjelp av denne metoden har han gitt oss ny innsikt i hvordan nervecellene kommuniserer med hverandre. Cornelia Bargmanns forskning har brakt oss et langt skritt videre i vår forståelse av hvordan sensoriske inntrykk omsettes i atferd (8). Dette har hun oppnådd ved å studere rundormen Caenorhabditis elegans (C. elegans).

Kavliprisene er ment å gi anerkjennelse til fremragende vitenskap og kreative forskere og skal styrke internasjonalt samarbeid. Men statuttene (2) viser at formålet går lenger: Prisene skal fremme forståelsen av vitenskap i samfunnet. Formidling er altså et nøkkelord. Personlig mener jeg at god ivaretakelse av formidlingsoppdraget er helt essensielt for at forskningspriser skal bygge legitimitet. Kavliprisene er intet unntak. I forbindelse med utdelingen arrangeres en rekke åpne foredrag for et bredt publikum. I fjor ble flere av disse foredragene holdt i Universitetets aula. De trakk fullt hus. Vi trenger enda mer av dette. Prisutdelingene må benyttes som en anledning til å «snakke fram» grunnforskningen, nettopp for å vise at det er nysgjerrighetsdrevet forskning som har brakt oss dit vi er i dag. Kavliprisene føyer seg til rekken av internasjonale priser som deles ut i Norge. Sammen med Nobels fredspris, Abelprisen og nordiske priser slik som Jahreprisen, bidrar Kavliprisene til at Norge settes på det internasjonale kartet.

Tilbake til Kavli selv. I et intervju sa han, på sin opprinnelige dialekt og med henvisning til gleden over sin filantropiske innsats: «Dæ norske storkaksan væt ikkje ka dæ går glipp tå» (1). Det var sikkert humor i dette, men også noe alvor. Heldigvis ser vi en stadig større filantropisk innsats også i Norge. Stadig flere investerer deler av sin formue i norsk forskning. Men det er langt igjen før vi har en amerikansk kultur for filantropi. For å komme dit må vi snakke fram forskningen. Og så må myndighetene gjeninnføre det sterke insitamentet som lå i gaveforsterkningsordningen. Dette kan gjøres allerede på neste statsbudsjett.

\section{Ole Petter Ottersen}

rektor@uio.no

Ole Petter Ottersen (f. 1955) er rektor ved Universitetet i Oslo. Han er selv hjerneforsker og overtar formannskapet i komiteen for Kavliprisen i nevrovitenskap, etter Jon Storm-Mathisen. Ottersen har tidligere ledet utdelingskomiteen for Jahreprisene og er styreleder i Anders Jahres fond til vitenskapens fremme.

Forfatter har fylt ut ICMJE-skjemaet og oppgir ingen interessekonflikter.

\section{Litteratur}

1. Jacobsen E. Den store filantropen. Bladet Forskning 2009; nr. 3. (www.forskningsradet.no/bladetforskning/Nyheter/Den_store_filantropen/ 1250810583762) (22.2.2013)

2. The Kavli Prize. www.kavliprize.no/(22.2.2013)

3. The Kavli Institute for Systems Neuroscience. www.ntnu.no/cbm/ (22.2.2013) . Kavli prize, $\S 1$ million award in nanoscience. www.nanogallery.info/nanogallery/ ? $r=29(22.2 .2013)$.

5. Overbye D. Seven scientists win Kavli prizes. www.nytimes.com/2012/05/31/ science/seven-scientists-win-kavli-prizes.html?_r=0 (22.2.2013).

6. Jog MS, Kubota $Y$, Connolly $\mathrm{Cl}$ et al. Building neural representations of habits. Science 1999; 286: 1745-9

7. Helmchen F, Fee MS, Tank DW et al. A miniature head-mounted two-photon microscope. high-resolution brain imaging in freely moving animals. Neuron 2001; 31: 903-12.

8. Chalasani SH, Chronis N, Tsunozaki M et al. Dissecting a circuit for olfactory behaviour in Caenorhabditis elegans. Nature 2007; 450: 63-70. 